Article

\title{
Environmental and Economic Evaluation of Small-Scale Bridge Repair Using Cross-Laminated Timber Floor Slabs
}

\author{
Tetsuya Iwase ${ }^{1}$, Takanobu Sasaki ${ }^{2}$, Shogo Araki ${ }^{3}$, Tomohumi Huzita ${ }^{4}$ and Chihiro Kayo ${ }^{5, *}$ \\ 1 Graduate School of Agriculture, Tokyo University of Agriculture and Technology, 3-5-8 Saiwai-cho, Fuchu, \\ Tokyo 183-8509, Japan; s185867v@st.go.tuat.ac.jp \\ 2 Research Faculty of Agriculture, Hokkaido University, Kita 9, Nishi 9, Kita-ku, Sapporo, \\ Hokkaido 060-8589, Japan; tak-sas@for.agr.hokudai.ac.jp \\ 3 Hattori Engineer Co., Ltd., 2-2-12 Miroku, Aoi-ku, Shizuoka, Shizuoka 420-0053, Japan; \\ s-araki@hattori-eng.co.jp \\ 4 United Graduate School of Agricultural Science, Tokyo University of Agriculture and Technology, \\ 3-5-8 Saiwai-cho, Fuchu, Tokyo 183-8509, Japan; s195462r@st.go.tuat.ac.jp \\ 5 Institute of Agriculture, Tokyo University of Agriculture and Technology, 3-5-8 Saiwai-cho, Fuchu, \\ Tokyo 183-8509, Japan \\ * Correspondence: kayoc@cc.tuat.ac.jp; Tel.: +81-42-367-5729
}

Received: 26 March 2020; Accepted: 21 April 2020; Published: 22 April 2020

\begin{abstract}
Cross-laminated timber (CLT) has gained popularity worldwide in recent years, and its use in buildings and civil engineering structures has attracted attention in Japan. In this study, the life-cycle greenhouse gas (GHG) balance and costs associated with CLT floor slabs were evaluated with respect to small-scale bridge repair as the first instance of the use of CLT in civil engineering projects in Japan. Additionally, waterproofing treatment was applied to CLT slabs, and the potential GHG and cost reduction of CLT in comparison with reinforced concrete (RC) slabs were examined. GHG emissions were the smallest for non-waterproofed CLT slabs and the greatest for RC slabs. When replacing RC slabs with CLT slabs without waterproofing, fossil-derived GHG emissions can be reduced by $73 \mathrm{~kg}-\mathrm{CO}_{2} \mathrm{eq} / \mathrm{m}^{2}$ per slab, and fossil/wood-derived GHG emissions can be reduced by $67 \mathrm{~kg}-\mathrm{CO}_{2} \mathrm{eq} / \mathrm{m}^{2}$; however, the use of disposed CLT as fuel is essential. Moreover, a reduction in GHG emissions can be expected if RC slabs are replaced with CLT slabs that are waterproofed only once every 20 years. Further, the cost associated with RC slabs is $20 \%$ of that attributable to CLT slabs. Hence, measures need to be taken to reduce the cost of CLT and waterproofing materials.
\end{abstract}

Keywords: cross-laminated timber; floor slabs; life-cycle assessment; greenhouse gas emissions; waterproofing treatment; reinforced concrete

\section{Introduction}

Timber is a renewable resource that is subject to sustainable forest management policies and its effective use supports a sustainable society. In particular, the effects of timber on carbon stock, as well as on material and fuel substitution, have been garnering attention as a tool to mitigate climate change; timber is an important aspect of various international climate change countermeasures [1].

In Japan, a major global timber consumer, this resource has been primarily used in construction, but the demand for timber as a building material has been declining due to a decrease in population and the subsequent slowing of housing construction. As a result, the use of timber in civil engineering projects is currently being promoted [2-7]. Bridges are a representative type of civil engineering projects in Japan. There are $\sim 720,000$ bridges in Japan, 660,000 of which are managed by local governments. 
More than $70 \%$ of these bridges are small-scale with a bridge length of less than $15 \mathrm{~m}$. Approximately $32 \%$ of small-scale bridges were over 50 years old as of 2019. This proportion is forecasted to increase to $59 \%$ by 2029 , only 10 years later, and each of these bridges will need to be updated or reinforced [8].

In recent years, cross-laminated timber (CLT), a new timber material, has been widely used in Europe, North America, and Australia [9-11]. CLT is a type of engineered wood in which lumber boards are glued side by side in a single layer and then glued to another layer of boards arranged at a $90^{\circ}$ angle from the adjacent layer, making it possible to manufacture thick and wide panels. Japanese CLT is produced from Japanese cedar, cypress, and larch woods, with a unit weight approximately $1 / 6$ to $1 / 4$ that of concrete $[12,13]$. Considering these advantages, it may be possible to refurbish the decks of aging bridges without reinforcing the girder or abutment by using lightweight CLT floor slabs of appropriate size (Figure 1) [12]. This is expected to reduce greenhouse gas (GHG) emissions and the economic burden on local governments.

Previous studies have investigated GHG emissions and economic factors related to the use of CLT in building construction [14-20] and the technical aspects of using CLT slabs [21,22]. However, the use of CLT slabs in civil structures such as bridges and the environmental and economic impacts of such projects have not been investigated.

We evaluated the GHG emissions of small-scale bridge repair in Akita Prefecture using CLT slabs as well as its associated costs, as determined by life-cycle assessment (LCA), as an example of the first use of CLT in civil engineering projects in Japan. The analysis herein focused on countermeasures that can stave off structural decay, as this decay is a potential disadvantage of CLT floor slabs; applying a waterproofing treatment appeared to be effective. In addition, we examined whether CLT slabs can reduce GHG emissions and cost in comparison to reinforced concrete (RC) slabs.

The life-cycle GHG balance per square meter of slab was calculated over a 50-year evaluation period. Net GHG emissions were the smallest for CLT slabs without waterproofing and the largest for RC slabs. When replacing RC slabs with CLT slabs without waterproofing, $73 \mathrm{~kg}-\mathrm{CO}_{2} \mathrm{eq} / \mathrm{m}^{2}$ fewer fossil-derived GHGs and $67 \mathrm{~kg}-\mathrm{CO}_{2} \mathrm{eq} / \mathrm{m}^{2}$ fewer fossil/wood-derived GHGs were emitted. However, the potential use of CLT as fuel after disposal is indispensable. When replacing RC slabs with CLT slabs with waterproofing treatment, only a minimal reduction in GHG can be expected. However, if waterproofing is only conducted every 20 years as part of routine maintenance, it is still possible to reduce GHG emissions by $18 \mathrm{~kg}-\mathrm{CO}_{2} \mathrm{eq} / \mathrm{m}^{2}$ for fossil-derived GHGs and $17 \mathrm{~kg}-\mathrm{CO}_{2} \mathrm{eq} / \mathrm{m}^{2}$ for fossiland wood-derived GHGs. In terms of cost, RC slabs are the least expensive, at only $18 \%$ of the cost of CLT slabs with waterproofing treatment and $16 \%$ of the cost of CLT slabs without waterproofing treatment. These results suggest that reducing the material cost of CLT and waterproofing materials is particularly important.

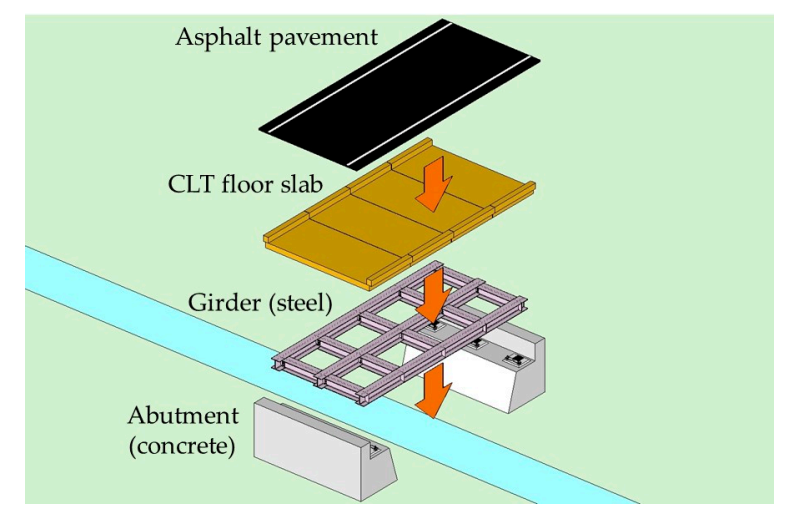

Figure 1. Image of a bridge using cross-laminated timber (CLT) floor slabs. 


\section{Materials and Methods}

\subsection{Bridges and Floor Slabs Targeted in This Study}

The bridge targeted for evaluation is located in Daisen City, Akita Prefecture, and is managed by the Akita prefectural government. This bridge was constructed in 1990 and has a length of $10 \mathrm{~m}$ and an effective width of $3.3 \mathrm{~m}$. At the start of construction in 1990, it had a simple structure in which a chestnut lumber floor slab was laid on the abutment and bridge girder. Over 25 years have passed since the bridge's erection and deterioration of the slab has progressed due to decay. Now, the slab must be replaced. Chestnut lumber lacks durability and is difficult to procure in Japan. Therefore, a slab using CLT made from Japanese cedar wood, a species widely used in Japanese construction, was adopted for the first time in Japanese bridge construction, and the bridge slabs were refurbished in 2018 [12,13]. As the abutment and bridge girder exhibited no problems related to deterioration, only the floor slabs and the pavement overlay were replaced.

Figure 2 shows a cross-sectional view, side view, and plan of the CLT slabs, and Figure 3 [23] shows an outline of the slab refurbishment. The CLT floor slabs were designed to withstand a load of $40 \mathrm{kN}$ based on the maximum weight of the vehicles passing over this bridge. As a result, five slabs with an area of $1990 \times 3450 \mathrm{~mm}$ and a thickness of $120 \mathrm{~mm}$ were laid. Wood decay is a concern when using CLT as a floor slab outdoors. Therefore, as a waterproofing and preservative treatment, a $2 \mathrm{~mm}$-thick polymeric cement waterproof material was applied to the CLT floor slab, and a surface protection material was also applied. CLT was also used for the ground-covering wood installed at both ends of the width, and the same waterproofing material and surface protection material were applied. Prior to installation of the CLT slabs, four auxiliary horizontal structures were welded on-site to the upper surface of the main girder and connected by metal brackets attached to the side of the slab to provide support. Next, hard rubber spacers were laid in the gap between the auxiliary horizontal structures. The upper surface of the slab was paved with a $50 \mathrm{~mm}$-thick recycled asphalt mixture.

Meanwhile, to equalize the function of RC and CLT slabs, RC slabs were designed to withstand the same load as CLT slabs. Based on this approach, the thickness of RC slabs was set to $160 \mathrm{~mm}$. As in the case of CLT slabs, the abutment and bridge girder were not reinforced or modified and recycled asphalt pavement was applied on the upper surface of RC slabs.

Regarding the mechanical properties of the main materials [24], tolerance levels of the weak and strong axes of the CLT slab significantly vary because the strength and rigidity of the material are set based on the lamination theory. When using CLT as a bending member, the tolerance level of the weak axis is low. CLT slabs are improved anisotropic materials. By contrast, RC slabs are isotropic composite materials of concrete and rebars, in which concrete is assumed to bear compressive force while the rebar handles tensile force. When RC slabs are used as a bending member, their properties can be easily modified by adjusting the volume of rebars. Note that CLT and RC slabs could exhibit different vibration characteristics [25] due to differences in their flexural rigidity. Nevertheless, we surmise that the effect of vibration on the floor slabs is little because the span length of floor slabs targeted in this study is as short as approximately $1 \mathrm{~m}$ (Figure 2). Therefore, the vibration characteristics will remain almost unchanged when RC slabs are replaced by CLT slabs. 
(a)

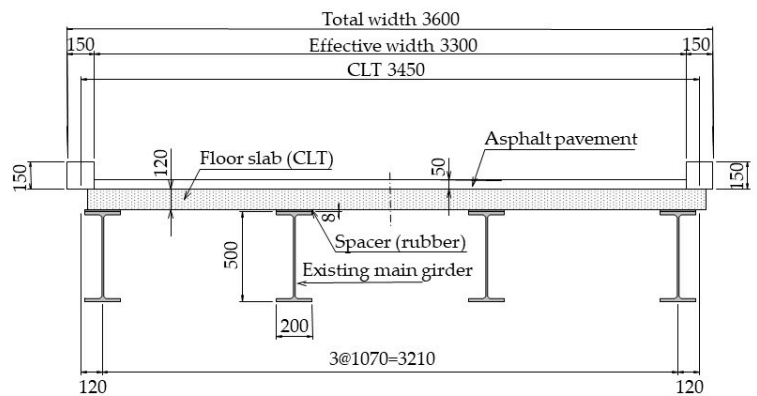

(b)

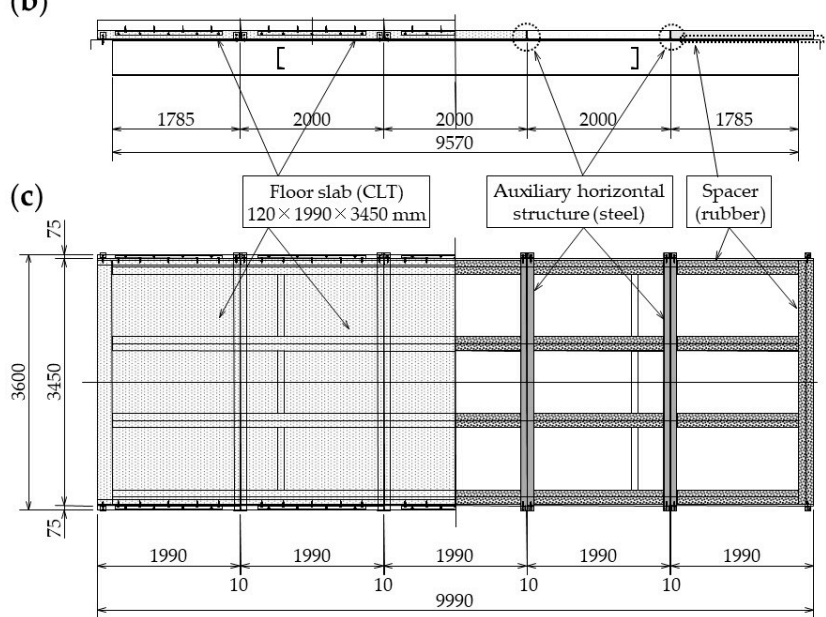

Figure 2. (a) Cross-sectional view, (b) side view, and (c) plan of CLT floor slabs.

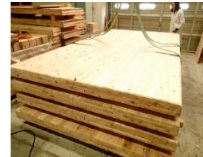

CLT slabs

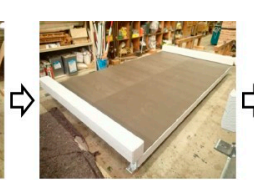

Waterproofing

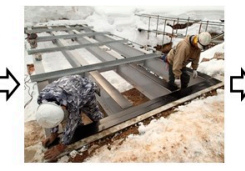

Installation of auxiliary horizontal structures and spacers

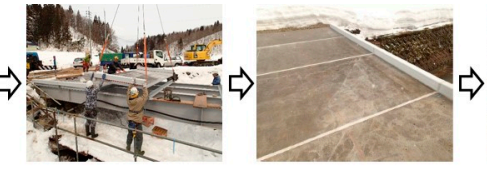

Installation of

CLT slabs

2

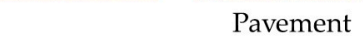

Figure 3. Outline of slab refurbishment.

\subsection{GHG Balance}

The life-cycle GHG balance for floor slab refurbishment was evaluated using the life-cycle assessment (LCA) method. LCA is a method for assessing environmental impact over the life-cycle of a target product [26]. The target slabs were CLT and RC. For CLT slabs, we examined cases with and without waterproofing treatment. The functional unit was the GHG balance per $\mathrm{m}^{2}$ of each slab over the course of a 50-year evaluation period. This life-cycle included material production and transport, construction, maintenance, and the disposal and recycling associated with floor slab refurbishment, whereas the processes of maintenance and disposal and recycling for abutments and bridge girders that did not require refurbishment were excluded. The life-cycle process (system boundary) is shown in Figure 4. We measured fossil-derived GHG $\left(\mathrm{CO}_{2}, \mathrm{CH}_{4}, \mathrm{~N}_{2} \mathrm{O}\right)$ emissions and reductions in each process (see Section 2.2.1 to Section 2.2.3) and used the 100-year global warming potential [27] to determine the quantity of GHG emissions converted to $\mathrm{CO}_{2}$. In addition, the GHG balance derived from wood (carbon stored in wood and GHG emitted from burning wood) was evaluated separately from the GHG balance derived from fossils (see Section 2.2.4). 


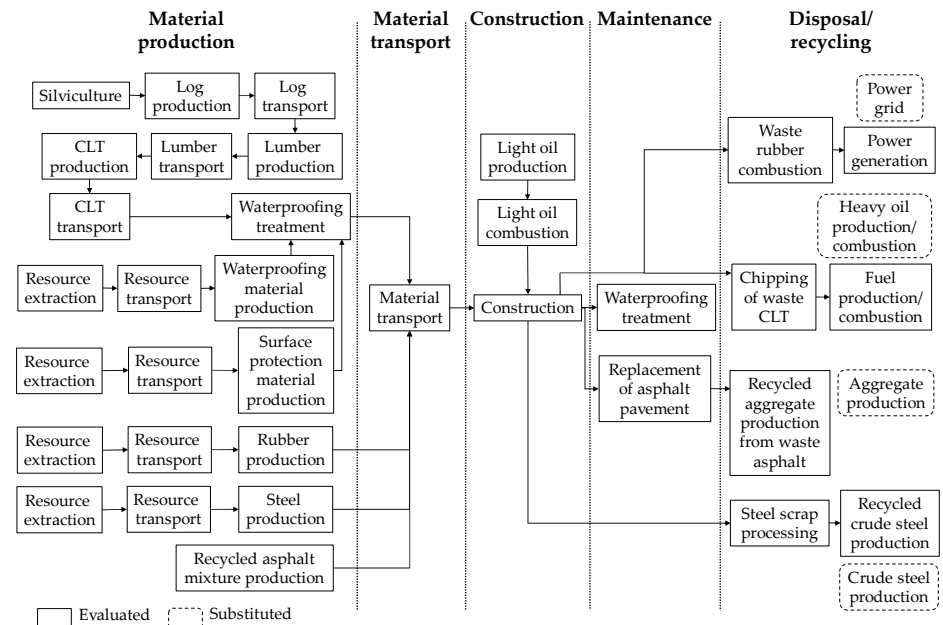

(a)

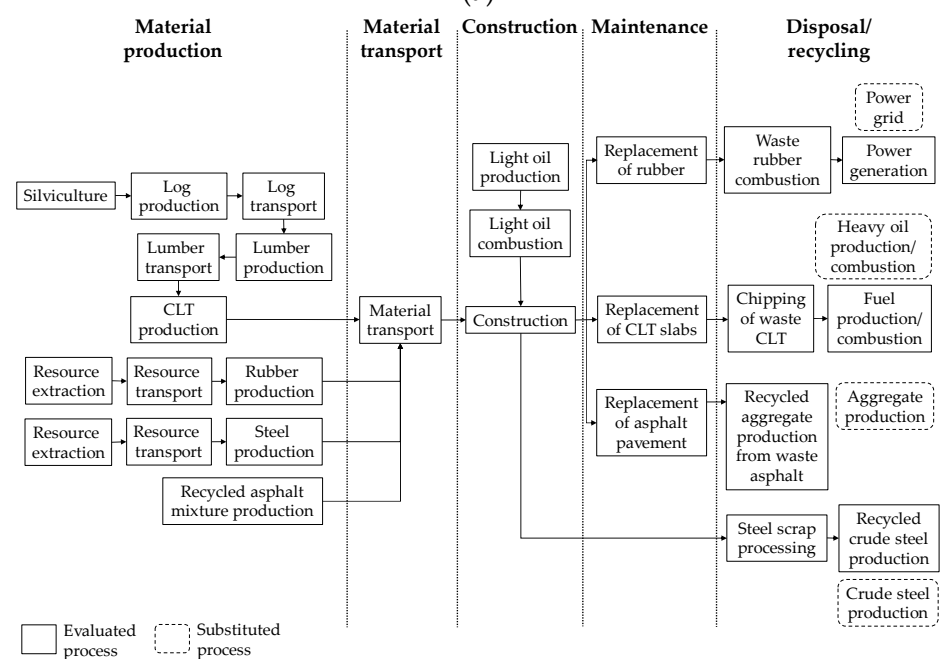

(b)

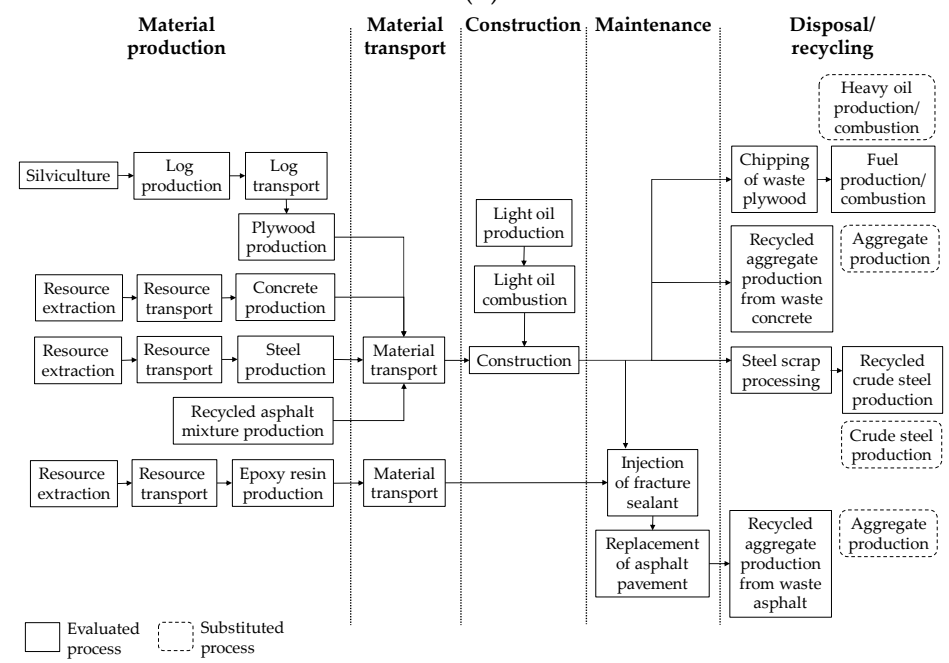

(c)

Figure 4. Life-cycle process: (a) waterproofed CLT floor slabs; (b) non-waterproofed CLT floor slabs; and (c) reinforced concrete (RC) floor slabs. 


\subsubsection{Material Production, Material Transport, and Construction Processes}

The quantity of materials and fuel used for floor slab refurbishment operations were collected through field surveys, interviews with design and construction contractors, and the acquisition of design estimate documentation. These quantities are summarized in Table 1. With respect to the material production process, GHG emissions were calculated by multiplying the quantity of material used by the GHG emission intensity associated with resource extraction, resource transport, and material production. The GHG emission intensities are summarized in Table 2 based on data extracted from the life-cycle inventory (LCI) database IDEAv2.1.3 [28]. Through interviews with CLT manufacturers, the fuel consumption associated with the production of CLT was found to be almost the same as that with glue laminated timber. Therefore, the emission intensity for glue laminated timber was used in IDEAv2.1.3. Regarding the material transport process, the distance transported could be determined for CLT slabs, but not for other materials. In particular, RC slabs required a calculation based on design only, so it was necessary to estimate the transport distance of each material. Under such constraints, it was determined that assuming transport conditions were virtually uniform across all materials would result in the least biased assessment (see Table 1), and as such all materials were assumed to have the same transport distance as CLT slabs, with the mode of transportation being a $10 \mathrm{t}$-capacity truck. GHG emissions were calculated by multiplying the amount of each material used by the transportation distance and the GHG emission intensity per truck. With respect to the construction process, GHG emissions were calculated by measuring the amount of light oil consumed by heavy machinery and multiplying this value by the GHG emission intensity for the production and combustion of light oil.

\subsubsection{Maintenance Process}

For the cases in which CLT floor slabs were waterproofed, waterproofing and surface protection materials were applied every 15 years; for the cases in which waterproofing was not performed, the CLT slabs and hard rubber spacers were presumed to be replaced every 15 years. The auxiliary horizontal structures were not refurbished or replaced regardless of waterproofing. The waterproofing application interval was determined based on interviews with design and construction companies, and the replacement interval for non-waterproofed CLT slabs was determined based on the legal service life of wooden bridges. For RC floor slabs, injection of an epoxy resin-based fracture sealant was performed every 25 years. The injection interval and the type of injection material were determined based on interviews with the bridge designers. Lastly, the asphalt pavement was replaced during each type of maintenance described above.

\subsubsection{Disposal/Recycling Process}

All materials were discarded and recycled 50 years after construction. This process includes the disposal and recycling of materials replaced in the above maintenance processes. The method for recycling each type of waste is described in detail below. Table 1 shows the amount of waste generated, and Table 2 shows the GHG emission intensity. 
Table 1. Material/fuel consumption and waste generation (unit/bridge).

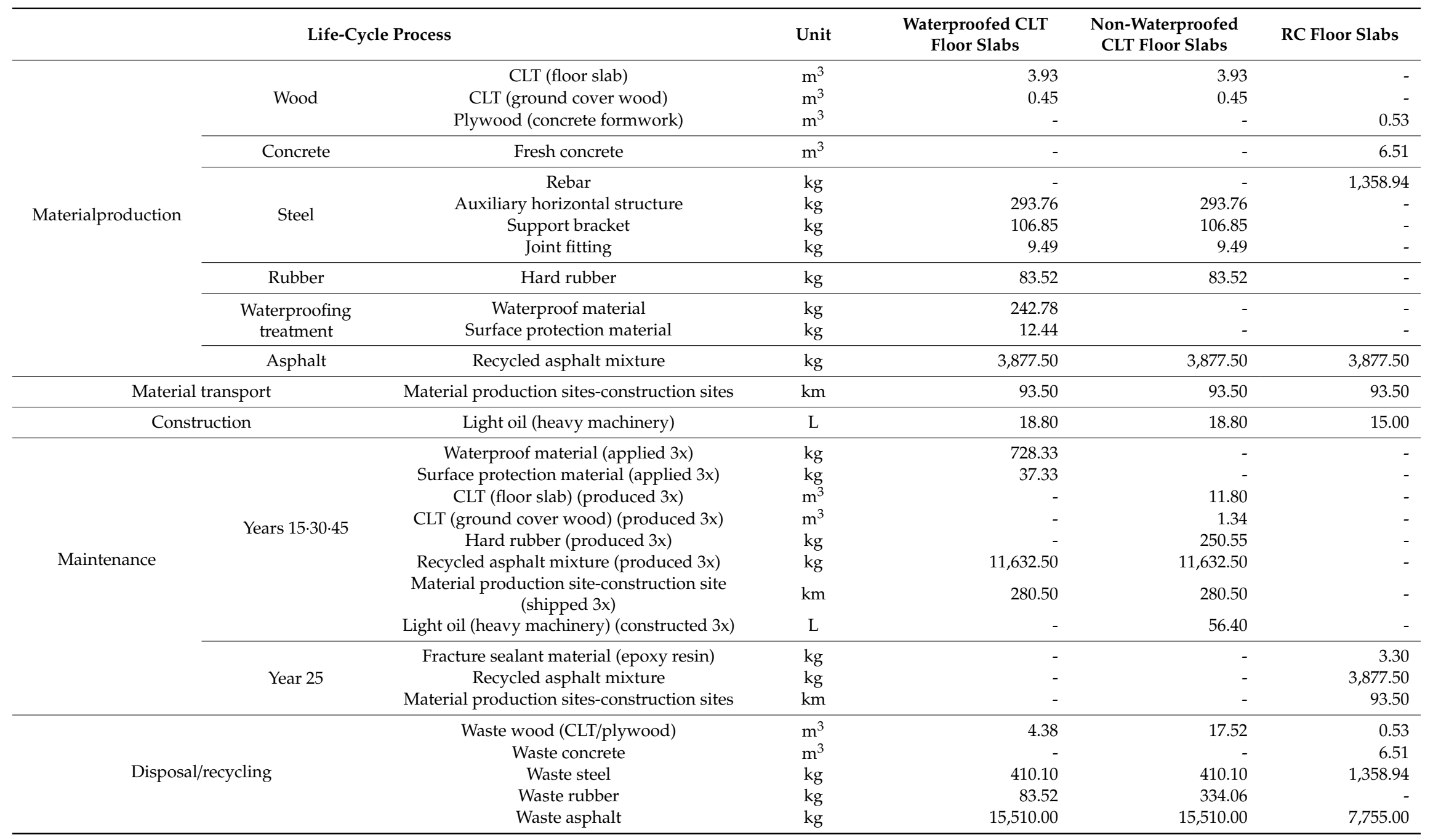


Table 2. Greenhouse gas (GHG) emission intensities (kg- $\left.\mathrm{CO}_{2} \mathrm{eq} / \mathrm{unit}\right)$.

\begin{tabular}{|c|c|c|}
\hline Material/Fuel Name & Unit & $\begin{array}{c}\text { GHG } \\
\text { Emissions }\end{array}$ \\
\hline Silviculture-log production-lumber production-CLT production & $\mathrm{m}^{3}$ & 233.647 \\
\hline Silviculture-log production-plywood production & $\mathrm{m}^{3}$ & 252.074 \\
\hline Resource extraction—fresh concrete production & $\mathrm{m}^{3}$ & 281.625 \\
\hline Resource extraction—rebar production & $\mathrm{kg}$ & 0.978 \\
\hline Resource extraction—auxiliary horizontal structure/support bracket production & $\mathrm{kg}$ & 2.690 \\
\hline Resource extraction-joint fitting production & $\mathrm{kg}$ & 2.349 \\
\hline Resource extraction—hard rubber production & $\mathrm{kg}$ & 5.184 \\
\hline Resource extraction—waterproofing material (ethylene) production & $\mathrm{kg}$ & 1.483 \\
\hline Resource extraction-waterproofing material (vinyl acetate) production & $\mathrm{kg}$ & 2.424 \\
\hline Resource extraction-waterproofing material (calcium silicate) production & $\mathrm{m}^{3}$ & 309.494 \\
\hline Resource extraction-waterproofing material (silica sand) production & $\mathrm{kg}$ & 0.015 \\
\hline Resource extraction—waterproofing material (iron oxide) production & $\mathrm{kg}$ & 0.006 \\
\hline $\begin{array}{c}\text { Resource extraction-production of waterproofing material/surface protection material } \\
\text { (industrial water) }\end{array}$ & $\mathrm{m}^{3}$ & 0.149 \\
\hline Resource extraction—surface protection material (methyl acrylate) production & $\mathrm{kg}$ & 3.166 \\
\hline Resource extraction—surface protection material (talc) production & $\mathrm{kg}$ & 0.033 \\
\hline Resource extraction—surface protection material (amorphous silica) production & $\mathrm{kg}$ & 1.665 \\
\hline Resource extraction-surface protection material (calcium carbonate) production & $\mathrm{kg}$ & 0.875 \\
\hline Recycled asphalt mixture production & $\mathrm{kg}$ & 0.048 \\
\hline Resource extraction-light oil production & $\mathrm{L}$ & 0.354 \\
\hline Light oil combustion & MJ & 0.078 \\
\hline Resource extraction-heavy oil production & $\mathrm{L}$ & 0.427 \\
\hline Heavy oil combustion & MJ & 0.080 \\
\hline Resource extraction—grid power (Tohoku Electric Power) generation & MJ & 0.166 \\
\hline Truck transportation (resource extraction-light oil production-light oil combustion) & $\mathrm{t} \cdot \mathrm{km}$ & 0.161 \\
\hline Resource extraction—fracture sealant material (epoxy resin) production & $\mathrm{kg}$ & 5.984 \\
\hline Waste wood combustion & MJ & 0.096 \\
\hline Steel scrap processing & $\mathrm{kg}$ & 0.018 \\
\hline Recycled crude steel production (electric arc furnace method) & $\mathrm{kg}$ & 0.646 \\
\hline Resource extraction-crude steel production (basic oxygen furnace method) & $\mathrm{kg}$ & 1.831 \\
\hline Recycled aggregate production & $\mathrm{kg}$ & 0.004 \\
\hline Resource extraction-aggregate production & $\mathrm{kg}$ & 0.011 \\
\hline Waste rubber combustion & MJ & 0.087 \\
\hline
\end{tabular}

Post-disposal, the CLT used in slabs and ground cover wood was repurposed as a combustible fuel and was assumed to partially replace the need for heavy oil. Specifically, waste wood was turned into chips, and heat was supplied by chip boilers to replace heavy oil boilers. The following Formulas (1) to (3) were used to calculate GHG reduction elicited by using waste wood as fuel:

$$
\begin{gathered}
\mathrm{RGE}_{\mathrm{W}}=\mathrm{GEE}_{\mathrm{H}}-\mathrm{GEE}_{\mathrm{W}} \\
\mathrm{GEE}_{\mathrm{H}}=\mathrm{DW} \cdot \mathrm{dw} \cdot \mathrm{cW} \cdot \mathrm{ehw} / \mathrm{ch} / \mathrm{ehh} \cdot\left(\mathrm{E}_{\mathrm{hp}}+\mathrm{E}_{\mathrm{hc}} \cdot \mathrm{ch}\right) \\
\mathrm{GEE}_{\mathrm{W}}=\mathrm{DW} \cdot \mathrm{LU} \cdot\left(\mathrm{E}_{\mathrm{lp}}+\mathrm{E}_{\mathrm{lc}} \cdot \mathrm{cl}\right)
\end{gathered}
$$

where $\mathrm{RGE}_{\mathrm{W}}\left(\mathrm{kg}-\mathrm{CO}_{2} \mathrm{eq}\right)$ is the reduction of GHG elicited by replacing the heavy oil used for fuel with waste wood, $\mathrm{GEE}_{\mathrm{H}}\left(\mathrm{kg}-\mathrm{CO}_{2} \mathrm{eq}\right)$ is the $\mathrm{GHG}$ emissions from the production and combustion of the heavy oil to be replaced, $\mathrm{GEE}_{\mathrm{W}}\left(\mathrm{kg}-\mathrm{CO}_{2} \mathrm{eq}\right)$ is the GHG emissions attributable to waste wood chip production, DW $\left(\mathrm{m}^{3}\right)$ is the amount of waste wood generated, $\mathrm{dw}\left(0.314 \mathrm{t} / \mathrm{m}^{3}\right)$ is the density of oven-dried cedar [29], cw (19,141 MJ/t) is the calorific value of oven-dried cedar wood [30], ehw (0.775) is the heat utilization efficiency of the wood chip boiler [31], ch (39.1 MJ/L) is the calorific value of heavy oil [28], ehh (0.885) is the heat utilization efficiency of the heavy oil boiler [31], $\mathrm{E}_{\mathrm{hp}}\left(\mathrm{kg}-\mathrm{CO}_{2} \mathrm{eq} / \mathrm{L}\right)$ is the GHG emission intensity from heavy oil production, $\mathrm{E}_{\mathrm{hc}}\left(\mathrm{kg}-\mathrm{CO}_{2} \mathrm{eq} / \mathrm{MJ}\right)$ is the GHG emission 
intensity from heavy oil combustion, $\mathrm{LU}\left(1.5 \mathrm{~L} / \mathrm{m}^{3}\right)$ is the light oil consumption from waste wood chip processing (interview survey with chip producers), $\mathrm{E}_{\mathrm{lp}}\left(\mathrm{kg}-\mathrm{CO}_{2} \mathrm{eq} / \mathrm{L}\right)$ is the GHG emission intensity from light oil production, $\mathrm{E}_{\mathrm{lc}}\left(\mathrm{kg}-\mathrm{CO}_{2} \mathrm{eq} / \mathrm{MJ}\right)$ is the $\mathrm{GHG}$ emission intensity from light oil combustion, and $\mathrm{cl}(37.3 \mathrm{MJ} / \mathrm{L})$ indicates the calorific value of light oil [28]. Although the surface of waste CLT is coated with waterproofing and surface protection materials, these materials meet the quality standard for wood chips for fuel use [32], and there have been no problems identified in connection to such use.

After the disposal of hard rubber spacers, a portion of the energy generated by the corresponding power grid was replaced by combustion of the waste rubber. Formulas (4) to (6) were used to calculate the reduction in GHG elicited by using waste rubber as fuel:

$$
\begin{gathered}
\mathrm{RGE}_{\mathrm{R}}=\mathrm{GEE}_{\mathrm{E}}-\mathrm{GEE}_{\mathrm{R}} \\
\mathrm{GEE}_{\mathrm{E}}=\mathrm{DR} \cdot \mathrm{cr} \cdot \mathrm{eer} \cdot \mathrm{E}_{\mathrm{ec}} \\
\mathrm{GEE}_{\mathrm{R}}=\mathrm{DR} \cdot \mathrm{cr} \cdot \mathrm{E}_{\mathrm{rc}}
\end{gathered}
$$

where $\mathrm{RGE}_{\mathrm{R}}\left(\mathrm{kg}-\mathrm{CO}_{2} \mathrm{eq}\right)$ is the reduction in GHG emissions achieved by replacing the grid power with power generated from waste rubber fuel, $\mathrm{GEE}_{\mathrm{E}}\left(\mathrm{kg}-\mathrm{CO}_{2} \mathrm{eq}\right)$ is the GHG emitted while supplying the power grid, $\mathrm{GEE}_{\mathrm{R}}\left(\mathrm{kg}-\mathrm{CO}_{2} \mathrm{eq}\right)$ is the GHG emissions from waste rubber combustion, $\mathrm{DR}(\mathrm{kg})$ is the amount of waste rubber generated, $\operatorname{cr}(29.3 \mathrm{MJ} / \mathrm{kg})$ is the calorific value of rubber [33], eer (0.19) is the power generation efficiency by incineration of waste rubber [34], $\mathrm{E}_{\mathrm{ec}}\left(\mathrm{kg}-\mathrm{CO}_{2} \mathrm{eq} / \mathrm{MJ}\right)$ is the GHG emission intensity from grid power (Tohoku Electric Power) generation, and $\mathrm{E}_{\mathrm{rc}}\left(\mathrm{kg}-\mathrm{CO}_{2} \mathrm{eq} / \mathrm{MJ}\right)$ indicates the GHG emission intensity from waste rubber combustion.

After the disposal of concrete and asphalt, production of new aggregate was replaced by the recycled aggregate produced from concrete and asphalt waste. The reduction in GHG emissions attributable to the use of waste concrete and asphalt as materials were calculated using the following Formulas (7) to (9):

$$
\begin{gathered}
\mathrm{RGM}_{\mathrm{C}}=\mathrm{GEM}_{\mathrm{A}}-\mathrm{GEM}_{\mathrm{C}} \\
\mathrm{GEM}_{\mathrm{A}}=\mathrm{DC} \cdot \mathrm{E}_{\mathrm{ap}} \\
\mathrm{GEM}_{\mathrm{C}}=\mathrm{DC} \cdot \mathrm{E}_{\mathrm{rp}}
\end{gathered}
$$

where $\mathrm{RGM}_{\mathrm{C}}\left(\mathrm{kg}-\mathrm{CO}_{2} \mathrm{eq}\right)$ is the reduction of GHG elicited by replacing new aggregate with recycled aggregate from waste concrete and asphalt, $\mathrm{GEM}_{\mathrm{A}}\left(\mathrm{kg}-\mathrm{CO}_{2} \mathrm{eq}\right)$ is the $\mathrm{GHG}$ emissions from the production of new aggregate to be replaced, GEMc $\left(\mathrm{kg}-\mathrm{CO}_{2} \mathrm{eq}\right)$ is the GHG emissions from the production of recycled aggregate, DC $(\mathrm{kg})$ is the amount of waste concrete and asphalt generated, $\mathrm{E}_{\mathrm{ap}}$ $\left(\mathrm{kg}-\mathrm{CO}_{2} \mathrm{eq} / \mathrm{kg}\right)$ is the GHG emission intensity from aggregate production, and $\mathrm{E}_{\mathrm{rp}}\left(\mathrm{kg}-\mathrm{CO}_{2} \mathrm{eq} / \mathrm{kg}\right)$ is the GHG emission intensity from the production of recycled aggregate. The yield when producing recycled aggregate from waste concrete and asphalt was assumed to be 1.0 [35], and it was assumed that the entire amount generated would be recycled.

After disposal of the steel materials such as rebars, auxiliary horizontal structures, and metal fittings, new crude steel was replaced by producing recycled crude steel from the waste steel. Specifically, crude steel produced by the electric arc furnace method after steel scrap processing was used to replace the new crude steel, which had been produced using the basic oxygen furnace method from iron ore. Formulas (10) to (12) were used to calculate the reduction in GHG elicited from the use of waste steel:

$$
\begin{gathered}
\mathrm{RGM}_{\mathrm{S}}=\mathrm{GEM}_{\mathrm{N}}-\mathrm{GEM}_{\mathrm{S}} \\
\mathrm{GEM}_{\mathrm{N}}=\mathrm{DS} \cdot \mathrm{ys} \cdot \mathrm{E}_{\mathrm{sc}} \\
\mathrm{GEM}_{\mathrm{S}}=\mathrm{DS} \cdot \mathrm{E}_{\mathrm{sp}}+\mathrm{DS} \cdot \mathrm{ys} \cdot \mathrm{E}_{\mathrm{se}}
\end{gathered}
$$


where $\mathrm{RGM}_{\mathrm{S}}\left(\mathrm{kg}-\mathrm{CO}_{2} \mathrm{eq}\right)$ is the reduction in GHG emissions elicited from the substitution of new crude steel with waste steel, $\mathrm{GEM}_{\mathrm{N}}\left(\mathrm{kg}-\mathrm{CO}_{2} \mathrm{eq}\right)$ is the GHG emissions from the production of new crude steel to be replaced, $\mathrm{GEM}_{\mathrm{S}}\left(\mathrm{kg}-\mathrm{CO}_{2} \mathrm{eq}\right.$ ) is the GHG emissions from the production of recycled crude steel, DS $(\mathrm{kg})$ is the amount of waste steel generated, ys (0.9) is the yield when processing from steel scrap to recycled crude steel [36], $\mathrm{E}_{\mathrm{sc}}\left(\mathrm{kg}-\mathrm{CO}_{2} \mathrm{eq} / \mathrm{kg}\right)$ is the GHG emission intensity attributable to crude steel production (basic oxygen furnace method), $\mathrm{E}_{\mathrm{sp}}\left(\mathrm{kg}-\mathrm{CO}_{2} \mathrm{eq} / \mathrm{kg}\right)$ is the GHG emission intensity from steel scrap processing, and $\mathrm{E}_{\mathrm{se}}\left(\mathrm{kg}-\mathrm{CO}_{2} \mathrm{eq} / \mathrm{kg}\right)$ is the $\mathrm{GHG}$ emission intensity from recycled crude steel production (electric arc furnace method).

\subsubsection{GHG Balance Derived from Wood}

The carbon stored in the CLT slabs and the plywood in the RC slabs was recorded as GHG reduction during the construction and maintenance processes. Meanwhile, $\mathrm{GHG}\left(\mathrm{CO}_{2}, \mathrm{CH}_{4}, \mathrm{~N}_{2} \mathrm{O}\right)$ emitted from the use of fuel after these woods were discarded was recorded as GHG emissions during the disposal and recycling process. Carbon storage was calculated by multiplying the amount of CLT or plywood used (Table 1) by the density of oven-dried wood $\left(0.314 \mathrm{t} / \mathrm{m}^{3}\right)$ [29] and the carbon content $(0.5 \mathrm{t}-\mathrm{C} / \mathrm{t})$ [29]. GHG emissions were calculated by multiplying the amount of CLT and plywood used by the GHG emission intensity from waste wood combustion (Table 2).

\subsection{Costs}

The costs associated with the refurbishment of floor slabs were evaluated. The evaluation target, evaluation period, and life-cycle process were the same as those used for the GHG balance evaluation. The direct construction costs (material costs and construction costs) in the construction process (including material production and transport) and those in the maintenance process as well as costs associated with waste disposal during the disposal or recycling process were obtained by conducting interviews with design and construction companies and obtaining design quote documentation; Tables 3 and 4 summarize the unit prices used for CLT and RC slabs, respectively. Consumption tax was not included.

Table 3. Unit price of materials, construction, and waste disposal costs for CLT slabs (JPY/unit).

\begin{tabular}{|c|c|c|c|c|}
\hline \multicolumn{3}{|c|}{ Life-Cycle Process/Expense Item } & \multirow{2}{*}{$\begin{array}{c}\text { Unit } \\
\text { Slabs }\end{array}$} & \multirow{2}{*}{$\begin{array}{l}\text { Price } \\
210,000\end{array}$} \\
\hline \multirow{19}{*}{$\begin{array}{l}\text { Construction/ } \\
\text { maintenance }\end{array}$} & \multirow{11}{*}{ Material costs } & CLT & & \\
\hline & & Hard rubber A & Sheets & 8260 \\
\hline & & Hard rubber B & Sheets & 7680 \\
\hline & & Hard rubber C & Sheets & 10,300 \\
\hline & & Auxiliary horizontal structure & Rods & 42,200 \\
\hline & & Support bracket A & Rods & 1900 \\
\hline & & Support bracket B & Rods & 8100 \\
\hline & & Joint fitting $\mathrm{A}$ & Rods & 260 \\
\hline & & Joint fitting B & Units & 40 \\
\hline & & Joint fitting $\mathrm{C}$ & Rods & 300 \\
\hline & & Recycled asphalt mixture & $\mathrm{m}^{2}$ & 2344 \\
\hline & \multirow{5}{*}{ Construction costs } & Bridge construction supervisors & Persons & 34,000 \\
\hline & & Bridge engineering specialists & Persons & 27,600 \\
\hline & & Carpenters & Persons & 25,800 \\
\hline & & Truck crane & Days & 43,000 \\
\hline & & Misc. expenses & Units & 32,200 \\
\hline & \multirow{3}{*}{$\begin{array}{c}\text { Material costs } \\
\text { (waterproofing treatment) }\end{array}$} & Waterproof material (base agent) & Cans & 36,600 \\
\hline & & Waterproof material (admixture) & $\mathrm{kg}$ & 6600 \\
\hline & & Surface protection material & Cans & 118,800 \\
\hline
\end{tabular}


Table 3. Cont.

\begin{tabular}{lcccr}
\hline & \multicolumn{2}{c}{ Life-Cycle Process/Expense Item } & Unit & Price \\
\hline & & Civil engineering supervisor & Persons & 25,200 \\
Construction/ & Construction costs & Specialist workers & Persons & 20,700 \\
maintenance & (waterproofing treatment) & Ordinary workers & Persons & 16,300 \\
& & Painters & Persons & 21,100 \\
& & Misc. expenses & Units & 13,530 \\
Disposal/ & Disposal and recycling & Waste wood & $\mathrm{m}^{3}$ & 4710 \\
recycling & costs & Waste steel & $\mathrm{t}$ & 2000 \\
& & Waste rubber & $\mathrm{t}$ & 26,000 \\
& & Waste asphalt & $\mathrm{t}$ & 1000 \\
\hline
\end{tabular}

Table 4. Unit price of materials, construction, and waste disposal costs for RC slabs (JPY/unit).

\begin{tabular}{|c|c|c|c|c|}
\hline \multicolumn{3}{|c|}{ Life-Cycle Process/Expense Item } & \multirow{2}{*}{$\frac{\text { Unit }}{\mathrm{m}^{2}}$} & \multirow{2}{*}{$\begin{array}{r}\text { Price } \\
761\end{array}$} \\
\hline \multirow{8}{*}{ Construction } & \multirow{5}{*}{ Material costs } & Plywood & & \\
\hline & & Rebar & $\mathrm{t}$ & 73,645 \\
\hline & & Fresh concrete & $\mathrm{m}^{3}$ & 14,700 \\
\hline & & Recycled asphalt mixture & $\mathrm{m}^{2}$ & 2344 \\
\hline & & Moldwork & $\mathrm{m}^{2}$ & 9259 \\
\hline & \multirow{3}{*}{ Construction costs } & Processing assembly & $\mathrm{t}$ & 58,000 \\
\hline & & Concrete casting & $\mathrm{m}^{3}$ & 4680 \\
\hline & & Slab curing & $\mathrm{m}^{2}$ & 428 \\
\hline \multirow{8}{*}{ Maintenance } & \multirow{5}{*}{ Material costs } & Fracture sealant material A & $\mathrm{kg}$ & 2890 \\
\hline & & Fracture sealant material B & $\mathrm{kg}$ & 2040 \\
\hline & & Injection device & Rods & 380 \\
\hline & & Recycled asphalt mixture & $\mathrm{m}^{2}$ & 2344 \\
\hline & & General supervisor & Persons & 26,400 \\
\hline & \multirow{3}{*}{ Construction costs } & Specialist workers & Persons & 22,400 \\
\hline & & Ordinary workers & Persons & 17,700 \\
\hline & & Misc. expenses & Units & 12,713 \\
\hline \multirow{4}{*}{ Disposal/recycling } & \multirow{4}{*}{$\begin{array}{l}\text { Disposal and } \\
\text { recycling costs }\end{array}$} & Waste wood & $\mathrm{m}^{3}$ & 4710 \\
\hline & & Waste concrete & $\mathrm{m}^{3}$ & 2350 \\
\hline & & Waste steel & $\mathrm{t}$ & 2000 \\
\hline & & Waste asphalt & $\mathrm{t}$ & 1000 \\
\hline
\end{tabular}

\section{Results and Discussion}

\subsection{GHG Balance}

Table 5 shows the evaluation of the life-cycle GHG balance over a 50-year period. The results of this evaluation are shown as GHG balance per $\mathrm{m}^{2}$ of slab by dividing by the slab area $\left(34 \mathrm{~m}^{2}\right)$.

Table 5. Life-cycle GHG balance during 50-year evaluation period ( $\mathrm{kg}-\mathrm{CO}_{2} \mathrm{eq} / \mathrm{m}^{2}$, +: emission, -: reduction).

\begin{tabular}{|c|c|c|c|c|c|c|c|}
\hline \multicolumn{2}{|c|}{ Life-Cycle Process } & \multicolumn{2}{|c|}{$\begin{array}{l}\text { Waterproofed CLT } \\
\text { Floor Slabs }\end{array}$} & \multicolumn{2}{|c|}{$\begin{array}{c}\text { Non-Waterproofed CLT } \\
\text { Floor Slabs }\end{array}$} & \multicolumn{2}{|c|}{ RC Floor Slabs } \\
\hline & & Fossil & Wood & Fossil & Wood & Fossil & Wood \\
\hline \multirow{6}{*}{$\begin{array}{c}\text { Material } \\
\text { production }\end{array}$} & Wood & 29.70 & - & 29.70 & - & 3.87 & - \\
\hline & Concrete & - & - & - & - & 53.16 & - \\
\hline & Steel & 31.92 & - & 31.92 & - & 38.57 & - \\
\hline & Rubber & 12.56 & - & 12.56 & - & - & - \\
\hline & $\begin{array}{l}\text { Waterproofing } \\
\text { treatment }\end{array}$ & 6.95 & - & - & - & - & - \\
\hline & Asphalt & 5.40 & - & 5.40 & - & 5.40 & - \\
\hline \multicolumn{2}{|c|}{ Material transport } & 2.51 & - & 2.51 & - & 9.04 & - \\
\hline \multicolumn{2}{|c|}{ Construction } & 1.78 & -73.17 & 1.78 & -73.17 & 1.42 & -8.83 \\
\hline
\end{tabular}


Table 5. Cont.

\begin{tabular}{|c|c|c|c|c|c|c|c|}
\hline \multicolumn{2}{|c|}{ Life-Cycle Process } & \multicolumn{2}{|c|}{$\begin{array}{l}\text { Waterproofed CLT } \\
\text { Floor Slabs }\end{array}$} & \multicolumn{2}{|c|}{$\begin{array}{c}\text { Non-Waterproofed CLT } \\
\text { Floor Slabs }\end{array}$} & \multicolumn{2}{|c|}{ RC Floor Slabs } \\
\hline & & Fossil & Wood & Fossil & Wood & Fossil & Wood \\
\hline \multirow{4}{*}{ Maintenance } & Year 15 & 14.16 & - & 49.99 & -73.17 & - & - \\
\hline & Year 25 & - & - & - & - & 7.67 & - \\
\hline & Year 30 & 14.16 & - & 49.99 & -73.17 & - & - \\
\hline & Year 45 & 14.16 & - & 49.99 & -73.17 & - & - \\
\hline \multirow{5}{*}{$\begin{array}{l}\text { Disposal/ } \\
\text { recycling }\end{array}$} & Wood & -60.37 & 74.72 & -241.47 & 298.86 & -7.28 & 9.01 \\
\hline & Concrete & - & - & - & - & -2.93 & - \\
\hline & Steel & -12.47 & - & -12.47 & - & -41.33 & - \\
\hline & Rubber & 3.94 & - & 15.75 & - & - & - \\
\hline & Asphalt & -2.97 & - & -2.97 & - & -1.48 & - \\
\hline \multicolumn{2}{|c|}{ Net GHG emissions } & 61.41 & 1.55 & -7.32 & 6.18 & 66.10 & 0.19 \\
\hline
\end{tabular}

\subsubsection{Comparison of CLT Floor Slabs with and without Waterproofing}

In comparisons between the fossil-derived GHG balance attributable to the use of CLT floor slabs with and without waterproofing, GHG emissions produced from the material production and maintenance processes for CLT slabs with waterproofing were $133 \mathrm{~kg}-\mathrm{CO}_{2} \mathrm{eq} / \mathrm{m}^{2}$, which was only $60 \%$ of the GHG emissions for that of the CLTs without waterproofing $\left(234 \mathrm{~kg}-\mathrm{CO}_{2} \mathrm{eq} / \mathrm{m}^{2}\right)$. For waterproofed CLT slabs, emissions are a result of the repeated production and application of the waterproofing and surface protecting materials every 15 years, whereas for CLT slabs without waterproofing treatment, emissions were generated by the repeated production of CLT and the related materials and fuels. Regardless of waterproofing, the emissions for steel and CLT were largely generated during the production of materials, accounting for approximately $70 \%-80 \%$ of total GHG emission during the material production process.

By contrast, when focusing on the disposal and recycling processes, the reduction in GHG emissions for non-waterproofed CLT slabs was $241 \mathrm{~kg}-\mathrm{CO}_{2} \mathrm{eq} / \mathrm{m}^{2}$, more than $330 \%$ greater than that of waterproofed CLT $\left(72 \mathrm{~kg}-\mathrm{CO}_{2} \mathrm{eq} / \mathrm{m}^{2}\right)$. The effect of replacing heavy oil by using waste CLT slabs as fuel following refurbishment was significant. For this reason, the net emissions volume, which is the quantity of emissions minus the amount of reduction, was $61 \mathrm{~kg}-\mathrm{CO}_{2} \mathrm{eq} / \mathrm{m}^{2}$ for slabs with waterproofing, and $-7 \mathrm{~kg}-\mathrm{CO}_{2} \mathrm{eq} / \mathrm{m}^{2}$ for slabs without waterproofing. Based on these findings, waterproofing is believed to be effective for reducing GHG emissions during maintenance, but when considering the disposal and recycling process, non-waterproofed slabs are believed to be more effective.

Regarding the GHG balance derived from wood, both emission and reduction were greater than those from fossil-derived GHG emissions for slabs without waterproofing; this is a result of the refurbishment of CLT slabs during maintenance and the combustion of waste CLT in the disposal and recycling process. In addition, regardless of waterproofing, GHG emissions produced during the disposal and recycling process were slightly greater than carbon storage during construction and maintenance, as $\mathrm{CH}_{4}$ and $\mathrm{N}_{2} \mathrm{O}$ emissions from the combustion of waste wood increased emissions.

\subsubsection{Comparison of CLT and RC Slabs}

In comparing the fossil-derived GHG balance of CLT slabs with that of RC slabs, GHG emissions $\left(119 \mathrm{~kg}-\mathrm{CO}_{2} \mathrm{eq} / \mathrm{m}^{2}\right)$ from the production of materials through maintenance of RC slabs were smaller than those for CLT slabs in $\sim 90 \%$ of cases involving waterproofed CLT slabs and in only $\sim 50 \%$ of cases involving non-waterproofed CLT slabs. In terms of material production processes, the emissions from the concrete and steel used in reinforced concrete were large for RC slabs, and the emissions produced in this process were greater than those for CLT slabs. However, during maintenance, the quantity of GHG emissions was significantly smaller for RC than CLT slabs, as fracture sealant is applied to RC slabs only once every 25 years. 
When considering the disposal and recycling process, the reduction in GHG emissions due to recycling the waste steel material of RC slabs was relatively large, but less than the reduction achieved by repurposing waste wood as fuel. The net emissions for RC floor slabs were $66 \mathrm{~kg}-\mathrm{CO}_{2} \mathrm{eq} / \mathrm{m}^{2}$. When replacing RC slabs with CLT slabs, the GHG reduction calculated when waterproofed CLT slabs were used was $5(=66-61) \mathrm{kg}-\mathrm{CO}_{2} \mathrm{eq} / \mathrm{m}^{2}$, and there is a high probability that GHG reduction will be minimal. By contrast, the reduction in GHG emissions for non-waterproofed CLT can be expected to be as large as $73(=66+7) \mathrm{kg}-\mathrm{CO}_{2} \mathrm{eq} / \mathrm{m}^{2}$, and it is possible to reduce $100 \%$ or more of the emissions produced by $\mathrm{RC}$ slabs. However, this requires the use of waste wood created during the disposal and recycling process as fuel.

There have been no previous studies using LCA with respect to CLT floor slabs used in bridge construction, and as such there are no results for a proper comparison against the results of this study. Nevertheless, we attempted to compare against previous research on the use of CLT in building construction. Previous studies have been conducted comparing the life-cycle GHG balance of CLT and concrete buildings [14], CLT and RC buildings [16,20], CLT and mineral buildings [17], and CLT flooring and RC flooring [19]. In these studies, CLT was reported to produce smaller quantities of GHGs than RC, etc., even without considering the reduction in GHG emissions during the disposal and recycling process. In this study, it was found that the GHG emissions attributable to CLT slabs were not less than those of RC slabs unless accounting for the reduction in GHG emissions realized during the disposal and recycling process. Compared to buildings built using CLT, the CLT floor slabs used in bridges are at the constant mercy of outdoor conditions, and the damage caused by vehicle traffic is expected to be substantial. For this reason, we assumed during this study that CLT slabs were re-coated with waterproofing material regularly or that slabs were replaced three times (at 15 -year intervals) during the 50-year evaluation period. On the other hand, RC slabs were assumed to be injected with sealant only once (every 25 years) during the evaluation period. Such assumptions greatly contributed to the different results of the previous and present studies.

When the fossil and wood-derived GHG balances calculated in this study are summed, the net GHG emissions were $63 \mathrm{~kg}-\mathrm{CO}_{2} \mathrm{eq} / \mathrm{m}^{2}$ for CLT slabs with waterproofing, $-1 \mathrm{~kg}-\mathrm{CO}_{2} \mathrm{eq} / \mathrm{m}^{2}$ for CLT slabs without waterproofing, and $66 \mathrm{~kg}-\mathrm{CO}_{2} \mathrm{eq} / \mathrm{m}^{2}$ for RC slabs. Therefore, even when the wood-derived GHG balance is taken into account, a negligible reduction in GHG emission is expected when RC slabs are replaced with waterproofed CLT slabs; however, when no waterproofing is applied, GHG emissions may be reduced by $67(=66+1) \mathrm{kg}-\mathrm{CO}_{2} \mathrm{eq} / \mathrm{m}^{2}$.

\subsubsection{Sensitivity Analysis}

As the data used in this study were collected primarily through interviews and design estimates, the evaluation results include uncertainties inherent to the data and setting conditions. Therefore, a sensitivity analysis was performed for factors that were considered to have a large degree of uncertainty and a significant impact on the results. The factors considered were as follows: use of waterproofing materials and surface protection materials on CLT floor slabs or GHG emissions due to their production increased by $5 \%$ (waterproof treatment $+5 \%$ ) or decreased by $5 \%$ (waterproof treatment $-5 \%$ ), the interval of refurbishment of CLT slabs, re-application of waterproofing material and surface protection material, and the sealant injection for RC slabs during maintenance was extended by 5 years (maintenance +5 years) or shortened by 5 years (maintenance -5 years), and the heat utilization efficiency of chip boilers for waste wood during disposal and recycling was made $5 \%$ higher than the current level $(77.5 \%$ ) (thermal efficiency $+5 \%$ ) or $5 \%$ lower (thermal efficiency $-5 \%$ ).

Table 6 shows the results of a sensitivity analysis of net GHG emissions. In all cases, the magnitude of net GHG emissions did not change between RC slabs and non-waterproofed CLT slabs. By contrast, for waterproofed CLT slabs, if the thermal efficiency of the wood chip boiler is reduced by $5 \%$ from the current level to $72.5 \%$ or lower, the fossil and wood-derived net GHG emissions increase compared to that of RC slabs. The thermal efficiency of the chip boiler greatly influences these results, and as such, improving thermal efficiency is important for the reduction of GHG emission. In addition, 
net GHG emissions for waterproofed CLT slabs exhibited a greater increase than those for RC slabs when the maintenance interval was shortened by 5 years, the re-application of the waterproofing material of CLT slabs was performed every 10 years, and sealant injection for RC slabs was performed every 20 years. Conversely, when the maintenance interval was extended by 5 years and re-coating of CLT slabs with the waterproofing material was performed every 20 years, the net GHG emissions of CLT slabs decreased significantly. In such cases, the net fossil and wood-derived GHG emissions attributable to CLT slabs were $50 \mathrm{~kg}-\mathrm{CO}_{2} \mathrm{eq} / \mathrm{m}^{2}, 75 \%$ of those of RC slabs. Here, by replacing RC slabs with CLT slabs, GHG reductions of $18 \mathrm{~kg}-\mathrm{CO}_{2} \mathrm{eq} / \mathrm{m}^{2}$ (fossil-derived) and $17 \mathrm{~kg}-\mathrm{CO}_{2} \mathrm{eq} / \mathrm{m}^{2}$ (fossil and wood-derived) can be expected, and it is important to consider extending the waterproofing interval as much as possible.

Table 6. Sensitivity analysis of net GHG emissions $\left(\mathrm{kg}-\mathrm{CO}_{2} \mathrm{eq} / \mathrm{m}^{2},+\right.$ : emission, - : reduction).

\begin{tabular}{ccrrrrr}
\hline & $\begin{array}{c}\text { Waterproofed CLT Floor Slabs } \\
\text { Fossil }\end{array}$ & \multicolumn{2}{c}{$\begin{array}{c}\text { Non-Waterproofed CLT Floor Slabs } \\
\text { Fossil }\end{array}$} & \multicolumn{2}{c}{$\begin{array}{c}\text { RC Floor Slabs } \\
\text { Foossil }\end{array}$} & Wood \\
\hline Current status & 61.41 & 1.55 & -7.32 & 6.18 & 66.10 & 0.19 \\
Waterproof treatment $+5 \%$ & 62.80 & 1.55 & -7.32 & 6.18 & 66.10 & 0.19 \\
Waterproof treatment $-5 \%$ & 60.02 & 1.55 & -7.32 & 6.18 & 66.10 & 0.19 \\
Maintenance +5 years & 48.00 & 1.55 & -0.14 & 4.64 & 66.10 & 0.19 \\
Maintenance -5 years & 74.83 & 1.55 & -14.50 & 7.73 & 73.03 & 0.19 \\
Thermal efficiency +5\% & 57.48 & 1.55 & -23.06 & 6.18 & 65.63 & 0.19 \\
Thermal efficiency -5\% & 65.35 & 1.55 & 8.42 & 6.18 & 66.58 & 0.19 \\
\hline
\end{tabular}

3.2. Costs

Table 7 shows the results of cost evaluation for the 50-year evaluation period.

Table 7. Costs during 50-year evaluation period (JPY/m²).

\begin{tabular}{|c|c|c|c|c|}
\hline \multicolumn{2}{|c|}{ Life-Cycle Process } & \multirow{2}{*}{$\begin{array}{l}\text { Waterproofed CLT } \\
\text { Floor Slabs } \\
30,465\end{array}$} & \multirow{2}{*}{$\begin{array}{c}\begin{array}{c}\text { Non-Waterproofed } \\
\text { CLT Floor Slabs }\end{array} \\
30,465\end{array}$} & \multirow{2}{*}{$\begin{array}{r}\text { RC Floor Slabs } \\
883\end{array}$} \\
\hline \multirow{8}{*}{ Construction } & Material costs (wood) & & & \\
\hline & Material costs (concrete) & & - & 2986 \\
\hline & Material costs (steel) & 9234 & 9234 & 3034 \\
\hline & Material costs (rubber) & 5854 & 5854 & - \\
\hline & Material costs (waterproofing) & 19,132 & - & - \\
\hline & Material costs (asphalt) & 2244 & 2244 & 2244 \\
\hline & $\begin{array}{l}\text { Construction costs } \\
\text { (construction site) }\end{array}$ & 8855 & 8855 & 14683 \\
\hline & $\begin{array}{l}\text { Construction costs } \\
\text { (waterproofing) }\end{array}$ & 8244 & - & - \\
\hline \multirow{4}{*}{ Maintenance } & $\begin{array}{l}\text { Material and construction costs } \\
\text { (Year 15) }\end{array}$ & 29,620 & 47,419 & - \\
\hline & $\begin{array}{l}\text { Material and construction costs } \\
\text { (Year 25) }\end{array}$ & - & - & 6699 \\
\hline & $\begin{array}{l}\text { Material and construction costs } \\
\text { (Year 30) }\end{array}$ & 29,620 & 47,419 & - \\
\hline & $\begin{array}{l}\text { Material and construction costs } \\
(\text { Year 45) }\end{array}$ & 29,620 & 47,419 & - \\
\hline \multirow{6}{*}{ Disposal/recycling } & $\begin{array}{l}\text { Disposal and recycling costs } \\
\text { (wood) }\end{array}$ & 599 & 2395 & 72 \\
\hline & $\begin{array}{l}\text { Disposal and recycling costs } \\
\text { (concrete) }\end{array}$ & - & - & 444 \\
\hline & $\begin{array}{l}\text { Disposal and recycling costs } \\
\text { (steel) }\end{array}$ & 24 & 24 & 79 \\
\hline & $\begin{array}{l}\text { Disposal and recycling costs } \\
\text { (rubber) }\end{array}$ & 63 & 252 & - \\
\hline & $\begin{array}{c}\text { Disposal and recycling costs } \\
\text { (asphalt) }\end{array}$ & 450 & 450 & 225 \\
\hline & Total costs & 174,025 & 202,029 & 31,348 \\
\hline
\end{tabular}




\subsubsection{Comparison of CLT Floor Slabs with and without Waterproofing}

With respect to the construction process, including material production and material transport, waterproofed and non-waterproofed CLT floor slabs have costs of $84,000 \mathrm{JPY} / \mathrm{m}^{2}$ and 57,000 JPY $/ \mathrm{m}^{2}$, respectively. However, when considering maintenance and disposal and recycling processes, waterproofed CLT slabs cost $174,000 \mathrm{JPY} / \mathrm{m}^{2}$, while those without waterproofing cost $202,000 \mathrm{JPY} / \mathrm{m}^{2}$. This is because it is cheaper to re-apply the waterproofing material than to replace CLT slabs during maintenance, and the reduced need for replacement also reduces the cost associated with the disposal of waste CLT.

\subsubsection{Comparison of CLT and RC Slabs}

The total cost of RC slabs was $31,000 \mathrm{JPY} / \mathrm{m}^{2}$, only $18 \%$ of the cost of waterproofed CLT slabs and $16 \%$ of the cost of non-waterproofed CLT slabs. Thus, the cost of RC slabs was significantly lower than that of CLT slabs. During construction, including the production and transportation of materials, the material cost of CLT slabs is $520 \%$ (without waterproofing) to $730 \%$ (with waterproofing) the cost of RC slabs, which also affects the increased costs associated with maintenance. A previous study comparing the costs of CLT flooring and RC flooring in buildings in Sweden [19] reported that the material cost of CLT flooring was higher than that of RC flooring, and the results of this study show a similar trend. In this study, in addition to the material cost of CLT, the material cost of waterproofing material and the surface protection material in the waterproofing process also contributed to the increase in total cost, and it is important to control these material costs.

\section{Conclusions}

In this study, the life-cycle GHG balance and costs attributable to CLT slabs used in small-scale bridge refurbishment over a 50-year period were evaluated as the first example of CLT use in civil engineering projects in Japan. In addition, we examined possible ways in which the GHG emissions and costs associated with CLT slabs may be reduced by comparing the application of waterproofing treatment to CLT slabs with those of general RC slabs.

In terms of GHG balance, fewer fossil-derived GHGs were emitted during the production of materials and maintenance for waterproofed CLT slabs than for non-waterproofed CLT slabs. However, when considering disposal and recycling, life-cycle GHG emissions were significantly smaller for non-waterproofed CLT slabs compared to those with waterproofing. If waterproofing treatment is not performed, a reduction in fossil-derived GHG emissions of $73 \mathrm{~kg}-\mathrm{CO}_{2} \mathrm{eq} / \mathrm{m}^{2}$ and $67 \mathrm{~kg}-\mathrm{CO}_{2} \mathrm{eq} / \mathrm{m}^{2}$ for fossil and wood-derived GHG emissions, respectively, can be achieved by replacing RC slabs with CLT slabs. However, it is essential to use CLT slabs as wood fuel after disposal. By contrast, for CLT slabs with waterproofing, even if RC slabs are replaced with CLT slabs, no significant GHG reduction effect can be expected. However, if the waterproofing material can be applied every 20 years, reductions of $18 \mathrm{~kg}-\mathrm{CO}_{2} \mathrm{eq} / \mathrm{m}^{2}$ for fossil-derived GHG emissions and $17 \mathrm{~kg}-\mathrm{CO}_{2} \mathrm{eq} / \mathrm{m}^{2}$ for fossil and wood-derived GHG emissions can be expected.

Meanwhile, in terms of cost, RC slabs are significantly cheaper, at only $18 \%$ of the cost of waterproofed CLT and $16 \%$ of the cost of non-waterproofed CLT slabs. Regarding the cost of CLT floor slabs themselves, the costs of CLT and waterproofing materials greatly contributed to the increase in total costs, and reducing these costs is an important issue for future consideration.

The use of CLT slabs in small bridges is more effective in reducing GHGs than the use of RC slabs; however, costs also increase, and the economic burden on the local governments as bridge managers may increase. Going forward, effective economic policies at the national level will be important alongside efforts to curb the cost of CLT and waterproofing materials.

Thus far, research on the environmental and economic evaluation of CLT used in civil engineering projects such as bridges is limited to the present study. Further research is required to obtain additional robust knowledge in this field. Nevertheless, the findings of this study will help policymakers 
examine the use of CLT in civil engineering structures globally and their waterproofing treatment using environmentally friendly and economical methods.

Author Contributions: Conceptualization, T.I. and C.K.; methodology, T.I., T.S., S.A., and C.K.; data curation, T.I., T.S., S.A., T.H., and C.K.; writing—original draft preparation, T.I.; writing-review and editing, T.S., S.A., T.H., and C.K.; funding acquisition, C.K. All authors have read and agreed to the published version of the manuscript.

Funding: This research was funded by the Japan Society for the Promotion of Science, grant number 16K21023 and The Sumitomo Foundation Fiscal 2019 Grant for Environmental Research Projects, grant number 193259.

Acknowledgments: We are deeply grateful to the bridge design and construction contractors and CLT manufacturers for providing invaluable data and assisting this study.

Conflicts of Interest: The authors declare no conflict of interest.

\section{References}

1. Intergovernmental Panel on Climate Change (IPCC). Climate Change 2014, Mitigation of Climate Change, Fifth Assessment Report; Cambridge University Press: New York, NY, USA, 2014.

2. Forestry Agency. Annual Report on Forest and Forestry in Japan (Fiscal Year 2013); Forestry Agency: Tokyo, Japan, 2014.

3. Forestry Agency. Annual Report on Forest and Forestry in Japan (Fiscal Year 2014); Forestry Agency: Tokyo, Japan, 2015.

4. Forestry Agency. Annual Report on Forest and Forestry in Japan (Fiscal Year 2015); Forestry Agency: Tokyo, Japan, 2016.

5. Forestry Agency. Annual Report on Forest and Forestry in Japan (Fiscal Year 2016); Forestry Agency: Tokyo, Japan, 2017.

6. Forestry Agency. Annual Report on Forest and Forestry in Japan (Fiscal Year 2017); Forestry Agency: Tokyo, Japan, 2018.

7. Forestry Agency. Annual Report on Forest and Forestry in Japan (Fiscal Year 2018); Forestry Agency: Tokyo, Japan, 2019.

8. Ministry of Land, Infrastructure, Transport and Tourism. Annual Report on Road Maintenance in Japan (Fiscal Year 2019); Ministry of Land, Infrastructure, Transport and Tourism: Tokyo, Japan, 2019.

9. Lehmann, S. Sustainable construction for urban infill development using engineered massive wood panel systems. Sustainability 2012, 4, 2707-2742. [CrossRef]

10. Hildebrandt, J.; Hagemann, N.; Thrän, D. The contribution of wood-based construction materials for leveraging a low carbon building sector in Europe. Sustain. Cities Soc. 2017, 34, 405-418. [CrossRef]

11. Ramage, M.H.; Burridge, H.; Busse-Wicher, M.; Fereday, G.; Reynolds, T.; Shah, D.U.; Wu, G.; Yu, L.; Fleming, P.; Densley-Tingley, D.; et al. The wood from the trees: The use of timber in construction. Renew. Sustain. Energy Rev. 2017, 68, 333-359. [CrossRef]

12. Sasaki, T. Potential of a new lightweight wooden material: Use of CLT (cross-laminated timber) in bridge floor slabs. Constr. Mach. Equip. 2018, 54, 28-33.

13. Toyoda, A.; Sasaki, T.; Araki, S.; Hayashi, T.; Ariyama, Y.; Gotou, H. Design and repairing of short span bridge using cross laminated timber slabs. J. Struct. Eng. 2019, 65A, 799-806.

14. Liu, Y.; Guo, H.; Sun, C.; Chang, W.-S. Assessing cross laminated timber (CLT) as an alternative material for mid-rise residential buildings in cold regions in China-A life-cycle assessment approach. Sustainability 2016, 8, 1047. [CrossRef]

15. Skullestad, J.L.; Bohne, R.A.; Lohne, J. High-rise timber buildings as a climate change mitigation measure-A comparative LCA of structural system alternatives. Energy Procedia 2016, 96, 112-123. [CrossRef]

16. Guo, H.; Liu, Y.; Meng, Y.; Huang, H.; Sun, C.; Shao, Y. A comparison of the energy saving and carbon reduction performance between reinforced concrete and cross-laminated timber structures in residential buildings in the severe cold region of China. Sustainability 2017, 9, 1426. [CrossRef]

17. Hafner, A.; Schäfer, S. Comparative LCA study of different timber and mineral buildings and calculation method for substitution factors on building level. J. Clean. Prod. 2017, 167, 630-642. [CrossRef]

18. Chen, C.X.; Pierobon, F.; Ganguly, I. Life cycle assessment (LCA) of cross-laminated timber (CLT) produced in western Washington: The role of logistics and wood species mix. Sustainability 2019, 11, 1278. [CrossRef] 
19. Hassan, O.A.B.; Öberg, F.; Gezelius, E. Cross-laminated timber flooring and concrete slab flooring: A comparative study of structural design, economic and environmental consequences. J. Build. Eng. 2019, 26, 100881. [CrossRef]

20. Pierobon, F.; Huang, M.; Simonen, K.; Ganguly, I. Environmental benefits of using hybrid CLT structure in midrise non-residential construction: An LCA based comparative case study in the U.S. Pacific Northwest. J. Build. Eng. 2019, 26, 100862. [CrossRef]

21. Ussher, E.; Arjomandi, K.; Weckendorf, J.; Smith, I. Prediction of Motion Responses of Cross-Laminated-Timber Slabs. In Structures; Elsevier: Amsterdam, The Netherlands, 2017; Volume 11, pp. 49-61.

22. Hassanieh, A.; Valipour, H.R.; Bradford, M.A. Composite connections between CLT slab and steel beam: Experiments and empirical models. J. Constr. Steel Res. 2017, 138, 823-836. [CrossRef]

23. Sasaki, T.; Yamauchi, H.; Adachi, K.; Hayashi, T. Water Resistance Evaluation of CLT Treated with Wrapping. In Proceedings of the 34th Annual Meeting of the Japan Wood Protection Association, Tokyo, Japan, 22-24 April 2018.

24. Machida, A.; Seki, H.; Usuki, S.; Masuda, N.; Himeno, K.; Watanabe, K. Construction Materials Science; Ohmsha, Ltd.: Tokyo, Japan, 2011.

25. Bedon, C. Experimental investigation on vibration sensitivity of an indoor glass footbridge to walking conditions. J. Build. Eng. 2020, 29, 101195. [CrossRef]

26. International Standards Organization (ISO). Environmental Management_Life-Cycle Assessment_Principles and Framework (ISO 14040), 2nd ed.; ISO: Geneva, Switzerland, 2006.

27. Intergovernmental Panel on Climate Change (IPCC). Climate Change 2013, The Physical Science Basis, Fifth Assessment Report; Cambridge University Press: New York, NY, USA, 2013.

28. National Institute of Advanced Industrial Science; Technology (AIST); Japan Environmental Management Association for Industry (JEMAI). LCI Database IDEA Version 2.1.3.; JEMAI: Tokyo, Japan, 2017.

29. Ministry of the Environment. Results of Greenhouse Gas Emission Calculations; Report No. 5 of Subcommittee Meetings on Forest Sinks; Ministry of the Environment: Tokyo, Japan, 2006.

30. Abe, F. Calorific value of Japanese coniferous wood. Bull. For. Prod. Res. Inst. 1986, 338, 91-100.

31. Japan Wood Energy Co., Ltd. Wood Biomass Boiler Installation Guide; Japan Wood Energy Co., Ltd.: Tokyo, Japan, 2012.

32. All Japan Wood-recycle Association. Quality Standard for Recycled Wood Chips; All Japan Wood-Recycle Association: Tokyo, Japan, 2010.

33. Kainou, K. RIETI Discussion Paper Series 14-J-047; Research Institute of Economy, Trade and Industry: Tokyo, Japan, 2014.

34. Plastic Waste Management Institute. Fundamental Knowledge of Plastic Recycling; Plastic Waste Management Institute: Tokyo, Japan, 2018.

35. Nakano, K.; Miura, H.; Wada, Y. The evaluation of environmental impact reduction by the waste asphalt concrete recycling. J. Jpn. Soc. Civil Eng. 1997, 559, 81-89.

36. The Japan Iron and Steel Federation. LCI Calculation Methodology for Steel Products; The Japan Iron and Steel Federation: Tokyo, Japan, 2015.

(C) 2020 by the authors. Licensee MDPI, Basel, Switzerland. This article is an open access article distributed under the terms and conditions of the Creative Commons Attribution (CC BY) license (http://creativecommons.org/licenses/by/4.0/). 